\title{
EFFECTS OF THE PREPARATION PERIOD TRAININGS ON BIOMOTORIC FEATURES OF 10-12 AGE MALE TENNIS PLAYERS ${ }^{1}$
}

\section{HAZIRLIK DÖNEMI ANTRENMANLARININ 10-12 YAŞ ERKEK TENISÇILERIN BIYYMOTORIK ÖZELLIKLERİ ÜZERINE ETKISI}

\author{
Mahmut ALP', Gürhan SUNA ${ }^{1}$, Barış BAYDEMIR ${ }^{2}$ \\ ${ }^{1}$ Süleyman Demirel University, Faculty of Sports Sciences, Sport Sciences Dep. Isparta / Turkey \\ ${ }^{2}$ Celal Bayar University, High School of Physical Education and Sports, Coaching Training Dep. Manisa / \\ Turkey
}

Öz: Amaç: Bu çalışmanın amacı, 10-12 yaş erkek tenisçilere uygulanan hazırlık dönemi antrenmanlarının biyomotorik özelliklerine etkisinin incelenmesidir. Araştırmaya Isparta ilinde bulunan, düzenli olarak tenis turnuvalarına ferdi katılan 10-12 yaş arası 20 erkek tenisçi katıldı. Tenisçilere 8 hafta, haftada 4 gün, günde en az 90 dakika uygulanan teknik ve koordinasyon geliştirici antrenman sürecinin başında ve sonunda sporculara kuvvet (şınav, mekik, dikey sıçrama, durarak uzun atlama), sürat $(5,10,20 \mathrm{~m})$, dayanıkl1lık (Shuttle Run) ve esneklik testleri uygulandi. Elde edilen veriler SPSS 18.0 istatistik programında "Paired t Testi" kullanılarak karşılaştırıldı. Tenisçilerin yaş ortalaması $11.05 \pm .88 \mathrm{y} 1$, boy ortalaması $144.50 \pm 7.87 \mathrm{~cm}$, vücut ağırlığı ortalaması ön test $38.72 \pm 9.51$ $\mathrm{kg}$, son test $38.83 \pm 9.35 \mathrm{~kg}$ olarak hesaplandi. Tenisçilere uygulanan tüm biyomotorik testlerin karşılaştırılması sonucunda istatistiksel olarak önemli derecede fark bulundu $(p<0,05)$. Literatüre bakıldığında araştırmamızı destekleyen birçok araştırma bulunmaktadır. Küçük yaş gruplarına uygulanan ve doğru yüklenme şiddetleri içeren teknik ve koordinasyon geliştirici antrenman drillerinin çocukların biyomotorik performansını artırdığı görülmüştür. İleride yapılacak olan çalışmalarda seçilecek antrenman modeli, kapsamı ve şiddeti bakımından araştırmamız antrenörlere ve spor bilimcilere öneriler sunmaktadır.

Anahtar Kelimeler: Tenis, Antrenman, Biyomotorik
Abstract: The aim of this study is to investigate the preparation period trainings' effects on biomotoric features of 10-12 age male tennis players. 20 male tennis players between age of 10-12 were joined to the study who are in Isparta and join tennis tournaments as individual regularly. At the beginning and ending of the trainings that applied 8 weeks, 4 day a week, at least 90 minutes a day; strength (push up, sit up, vertical jump, standing long jump), speed $(5,10,20 \mathrm{~m})$, endurance (Shuttle Run) and flexibility tests were applied to the players. Handled datas were compared by using "Paired t Test" at SPSS 18.0 statistic programme. These were calculated from tennis players' mean of age was $11.05 \pm .88$ year, mean of length was $144.50 \pm 7.87 \mathrm{~cm}$, mean of pre weight was $38.72 \pm 9.51 \mathrm{~kg}$, mean of post weight was $38.83 \pm 9.35 \mathrm{~kg}$. As a result of comparing all tests applied to the players, differences were found to be statistically significiant $(p<0,05)$. Referring to literature, there are many studies that support our research. It was defined that technic and coordination improvement training drills applied to small age groups and contained true loading densities, increased the biomotoric performance of children. Our study offers trainers and sport scientists suggestions with regard to choose training model, content and density for studies in future.

Key Words: Tennis, Training, Biomotoric

Doi: 10.17363/SSTB.20161816487

(1) Corresponding Author: Mahmut ALP, Süleyman Demirel University, Faculty of Sports Sciences, Sport Sciences Dep. Isparta / Turkey mahmutalp1907@hotmail.com Received: 19.12.2015 Accepted: 18.03.2016 Type ofarticle (Research -Application) Conflict of Interest: None / "None of Ethics Committee" 


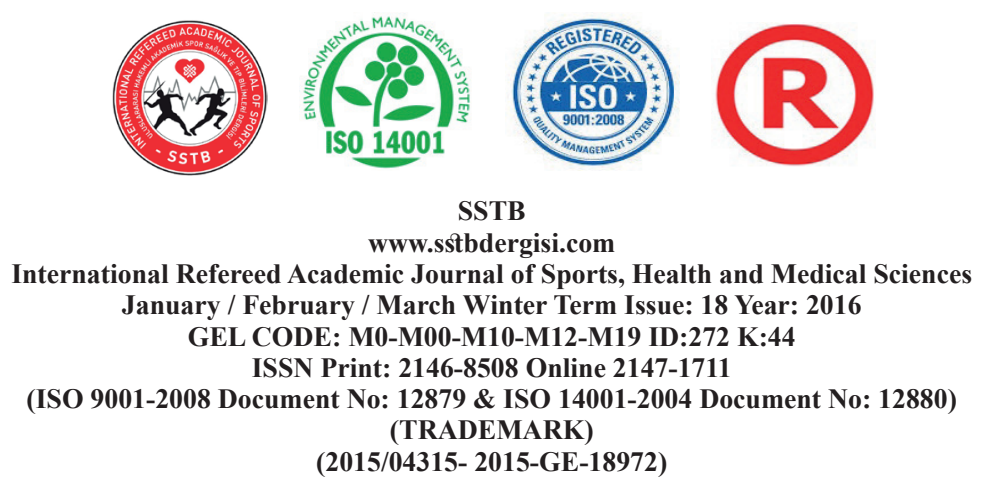

\section{INTRODUCTION}

All sports activities requires different levels of physical, physiological and biomotoric qualification during both applying and learning. These qualifications means using the force with required format in the implementation of sporting activities. This use represents doing the movement accurately with experience and learning (Mengütay, 1999: 3-6). Athletic skills must be trained in order to develop them (Gelen et al., 2009: 2-4).

Biomotoric features occurs from strength, speed, endurance, flexibility, agility, coordination. In gameplay and combat sports (tennis, football, judo, boxing), techniques and tactics are used with conditional attributes. To improve these properties, various training drills of specisific styles are applied. Implementation of specific branches of the style and to be considered during the implementation of individual differences are the most important details. These details are made without taking into account the practice increases the risk of occurrence of disability or inadequate development of athletes as biomotoric (Ölçücü, 2010: 2-3).

Tennis is a sport that has interested by individuals from each category either recreational or professional and has a continuous growth in the world. Participation of sports is the most important element and also applied ear- ly age in other sports, plays a major role in selecting talented children in tennis. To develop biomotoric features besides basic strokes, ability of athletes are important for coaches who want to achieve success. Strength, coordination, speed and agility of children can be improved with appropriate training programs. Players that have well biomotoric features, have advantages over their competitors. They can move and think faster than their competitors, have quick recovery after a long period of time they score, they are less tired, less risk of injury and the continuity of strength. In other words, the difference between winning and losing depends on the biomotoric features (Çalışkan, 2014: 2-3).

In light of these informations obtained from the literature, the purpose of our study was to investigate the preparation period trainings' effects on biomotoric features of 10-12 age male tennis players.

\section{MATERIALS and METHODS}

20 male athletes participated to the study who were 10-12 age in Isparta. "Informed Consent Form" were taken from parents of students, then the explanation was done that personal informations and datas obtained before and after the research, strictly to be kept. The research group were trained tennis and coordination trainings as 8 weeks, 4 days a week, 90 minutes a day. All training and measurements 
GEL CODE: M0-M00-M10-M12-M19 ID:272 K:44

ISSN Print: 2146-8508 Online 2147-1711

(ISO 9001-2008 Document No: 12879 \& ISO 14001-2004 Document No: 12880)

of the study group were taken at Süleyman

Demirel University Tennis Center Building.

Table 1. Weekly Training Content

\begin{tabular}{|c|c|c|c|c|}
\hline & MONDAY & TUESDAY & THURSDAY & SATURDAY \\
\hline $\begin{array}{l}\text { 1. \& } 2 . \\
\text { WEEKS } \\
\text { Loading } \\
\text { Density \%50 }\end{array}$ & $\begin{array}{l}-20 \text { min warm up } \\
-60 \text { min technic drill } \\
\text { trainings } \\
-10 \text { min cool down- } \\
\text { strecthing }\end{array}$ & $\begin{array}{l}-20 \text { min warm up } \\
-30 \text { min velocity trainings }(3 \times 2 \text { sets } \\
-5 \text { min rest bet. sets }) \\
-10 \text { min cool down-strecthing }\end{array}$ & $\begin{array}{l}-20 \text { min warm up } \\
-40 \text { min technic drill } \\
\text { trainings } \\
-25 \text { min rally } \\
-5 \text { min cool down- } \\
\text { strecthing }\end{array}$ & $\begin{array}{l}-20 \text { min warm up } \\
-60 \text { min rally at minicourt and } \\
\text { baseline } \\
-5 \text { min cool down-strecthing }\end{array}$ \\
\hline $\begin{array}{l}\text { 3. \& } 4 . \\
\text { WEEKS } \\
\text { Loading } \\
\text { Density \%60 }\end{array}$ & $\begin{array}{l}-20 \text { min warm up } \\
-40 \text { min technic drill } \\
\text { trainings } \\
-20 \text { min. rally } \\
-10 \text { min cool down- } \\
\text { strecthing }\end{array}$ & $\begin{array}{l}-20 \text { min warm up } \\
-30 \text { min velocity trainings } \\
\text { - work out trainings } 2 \times 3 \text { set } \\
-5 \text { min rest bet. sets } \\
-3 \times 100 \text { rope jump } \\
-5 \text { min rest bet. sets } \\
-10 \text { min cool down-strecthing }\end{array}$ & $\begin{array}{l}-20 \text { min warm up } \\
-40 \text { min technic drill } \\
\text { trainings) } \\
-20 \text { min rally at baseline } \\
-10 \text { min cool down- } \\
\text { strecthing }\end{array}$ & $\begin{array}{l}-20 \text { min warm up } \\
-40 \text { min technic drill trainings } \\
-20 \text { min rally at baseline } \\
-10 \text { min cool down-strecthing }\end{array}$ \\
\hline $\begin{array}{c}\text { 5. \& } 6 . \\
\text { WEEKS } \\
\text { Loading } \\
\text { Density \%70 }\end{array}$ & $\begin{array}{l}-20 \text { min warm up } \\
-40 \text { min technic drill } \\
\text { trainings } \\
-20 \text { min rally } \\
-10 \text { min cool down- } \\
\text { strecthing }\end{array}$ & $\begin{array}{l}-20 \text { min warm up } \\
-30 \text { min velocity trainings } \\
- \text { stair training ( } 50 \text { steps) } 3 \times 3 \text { sets } \\
-6 \text { min rest bet. sets } \\
- \text { theraband trainings ( forehand- } \\
\text { backhand) } 4 \times 20 \\
-5 \text { min rest bet. sets } \\
-10 \text { min cool down-strecthing }\end{array}$ & $\begin{array}{l}-20 \text { min warm up } \\
-15 \text { min rally at minicourt } \\
-45 \text { min match } \\
-10 \text { min cool down- } \\
\text { strecthing }\end{array}$ & $\begin{array}{l}-20 \text { min warm up } \\
-40 \text { min technic drill trainings } \\
-20 \text { min rally at baseline } \\
-10 \text { min cool down-strecthing }\end{array}$ \\
\hline $\begin{array}{c}\text { 7. \& } 8 . \\
\text { WEEKS } \\
\text { Loading } \\
\text { Density } \% 80\end{array}$ & $\begin{array}{l}-20 \text { min warm up } \\
-15 \text { min minicourt rally } \\
-20 \text { min rally at baseline } \\
-30 \text { min match } \\
-10 \text { min cool down- } \\
\text { strecthing }\end{array}$ & $\begin{array}{l}-20 \text { min warm up } \\
-30 \text { min velocity trainings } \\
-6 \text { min rest bet. sets } \\
- \text { foot velocity drills } 3 \times 3 \text { set } \\
-6 \text { min rest bet.sets } \\
-10 \text { min cool down-strecthing }\end{array}$ & $\begin{array}{l}-15 \text { min warm up } \\
-15 \text { min rally at minicourt } \\
-50 \text { min match } \\
-10 \text { min cool down- } \\
\text { strecthing }\end{array}$ & $\begin{array}{l}-20 \text { min warm up } \\
-15 \text { min rally at minicourt } \\
-50 \text { min rally } \\
-10 \text { min cool down-strecthing }\end{array}$ \\
\hline
\end{tabular}

Strength Test: Athletes' number of push-ups and sit-ups in 30 seconds were recorded as they could do.

Vertical Jump Test: Free vertical jump test was applied to athletes. The best results were recorded as "cm" from tool measuring digitally. "Takei jumper meters" was used with measurement capacity between $5 \mathrm{~cm}$ to 99 $\mathrm{cm}$, showing the distance digitally by leaping with waist stuck.
Standing Long Jump Test: The Jump was told to athletes to be precipitating with the open position squat down, half feet shoulder width, and then back to the arm supporting the thrust of the forward movement of the leg, as far as possible away (forward). The best jump value was recorded as "cm" after the starting point drop from heel and foot.

Speed Test: 5, 10 and $20 \mathrm{~m}$ sprint tests were applied to the athletes based on standart half 


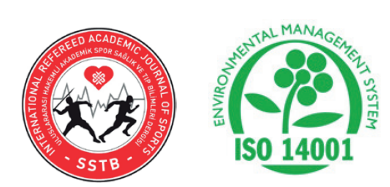

SSTB

Www.sstbdergisi.com

International Refereed Academic Journal of Sports, Health and Medical Sciences

January / February / March Winter Term Issue: 18 Year: 2016

GEL CODE: M0-M00-M10-M12-M19 ID:272 K:44

ISSN Print: 2146-8508 Online 2147-1711

(ISO 9001-2008 Document No: 12879 \& ISO 14001-2004 Document No: 12880)

(TRADEMARK)

(2015/04315- 2015-GE-18972)

the size of a tennis court. Scores recorded with Casio (USA) brands stopwatch precision $1 / 1000 \mathrm{sec}$.

Endurance Test (Shuttle Run): Marks were put the beginning and the end of tennis court based on the trail adapted $20 \mathrm{~m}$ half of the field and the athletes were given audio signal tool. It was required to be within two meters in each volume of the athletes in front of the start and finish line. Athletes were built 20 minutes warming up before starting the test.

Flexibility Test: The most remote spots flexibility distances were recorded with students' sit-reach flexibility test. General warm-up was done for athletes with leg and back muscles before this test. Measurements were repeated 3 times and the value was recorded.

Data Analysis: Analysis of datas statistically were made by using "Paired t Test" in SPSS 18.0 programme (Statistical Package for Social Sciences). Results were evaluated based on “*** $p<0.05, * * p<0.01, * p<0.001$ ” the significance levels.

\section{FINDINGS}

Table 2. Physical Features of Tennis Players

\begin{tabular}{|c|c|c|c|c|}
\hline $\begin{array}{l}\text { PARAMETERS } \\
(\mathrm{n}=\mathbf{2 0})\end{array}$ & Minimum & Maximum & Mean \pm SD & $\mathbf{p}$ \\
\hline Age (year) & 10.00 & 12.00 & $11.05 \pm .88$ & \\
\hline Height (cm) & 127.00 & 156.00 & $144.50 \pm 7.87$ & \\
\hline \multirow{2}{*}{ Weight (kg) } & \multicolumn{2}{|c|}{ Pre Test } & $38.72 \pm 9.51$ & \multirow{2}{*}{$.037 * * *$} \\
\hline & \multicolumn{2}{|c|}{ Post Test } & $38.83 \pm 9.35$ & \\
\hline
\end{tabular}

$* * * \mathbf{p}<0.05, * * \mathbf{p}<0.01, * \mathbf{p}<0.001$

Players' mean of age was $10.26 \pm 1.27$ years, mean of height was $143.33 \pm 8.02 \mathrm{~cm}$ and mean of weight in pre-test $37.96 \pm 9.77 \mathrm{~kg}$; in post-test $38.03 \pm 9.56 \mathrm{~kg}$. As a result of comparison weight, differences found to be statistically significant $(\mathrm{p}<0.05)$. 
www.sstbdergisi.com

International Refereed Academic Journal of Sports, Health and Medical Sciences January / February / March Winter Term Issue: 18 Year: 2016

GEL CODE: M0-M00-M10-M12-M19 ID:272 K:44

ISSN Print: 2146-8508 Online 2147-1711

(ISO 9001-2008 Document No: 12879 \& ISO 14001-2004 Document No: 12880)

(TRADEMARK)

(2015/04315- 2015-GE-18972)

Table 3. Paired t Test Results of Players' Strength Pre and Post Test Means

\begin{tabular}{lcccc} 
STRENGTH TESTS & $\begin{array}{c}\text { Test } \\
\text { Sequence }\end{array}$ & Mean \pm SD & t & p \\
\cline { 1 - 3 } Push-up (number/30 sec) & Pre Test & $24.45 \pm 7.63$ & -13.76 & $\mathbf{. 0 0 0 *}$ \\
\cline { 2 - 4 } & Post Test & $\mathbf{2 8 . 6 0} \pm 7.99$ & & \\
\hline Sit-up (number/30 sec) & Pre Test & $22.60 \pm 3.64$ & -13.48 & $\mathbf{. 0 0 0 *}$ \\
\hline & Post Test & $\mathbf{2 6 . 8 5} \pm \mathbf{4 . 1 5}$ & & \\
\hline & Post Test & $\mathbf{1 5 3 . 8 0} \pm \mathbf{1 1 . 9 4}$ & & \\
\hline
\end{tabular}

$* * * \mathbf{p}<0.05, * * \mathbf{p}<0.01, * \mathbf{p}<0.001$

There were found differences statistically as a result of comparison of players' strength pre and post test values $(\mathrm{p}<0.05)$.

Table 4. Paired t Test Results of Players' Speed Pre and Post Test Means

\begin{tabular}{|c|c|c|c|c|}
\hline SPEED TESTS & $\begin{array}{c}\text { Test } \\
\text { Sequence }\end{array}$ & $\operatorname{Mean} \pm$ SD & $\mathbf{t}$ & $\mathbf{p}$ \\
\hline \multirow{2}{*}{5 meters (sec) } & Pre Test & $1.23 \pm .10$ & \multirow{2}{*}{8.18} & \multirow{2}{*}{$.000 *$} \\
\hline & Post Test & $1.18 \pm .10$ & & \\
\hline \multirow{2}{*}{10 meters (sec) } & Pre Test & $2.25 \pm .13$ & \multirow{2}{*}{15.98} & \multirow{2}{*}{.000} \\
\hline & Post Test & $2.20 \pm .13$ & & \\
\hline \multirow[t]{2}{*}{20 meters (sec) } & Pre Test & $3.99 \pm .27$ & 10.64 & $.000 \%$ \\
\hline & Post Test & $3.92 \pm .27$ & & \\
\hline
\end{tabular}

$* * * \mathbf{p}<0.05, * * \mathbf{p}<0.01,{ }^{*} \mathbf{p}<0.001$

Differences found to be statistically significant as a result of comparison of players' speed pre and post test values $(\mathrm{p}<0.05)$. 
SSTB

Www.sstbdergisi.com

International Refereed Academic Journal of Sports, Health and Medical Sciences

January / February / March Winter Term Issue: 18 Year: 2016

GEL CODE: M0-M00-M10-M12-M19 ID:272 K:44

ISSN Print: 2146-8508 Online 2147-1711

(ISO 9001-2008 Document No: 12879 \& ISO 14001-2004 Document No: 12880)

(TRADEMARK)

(2015/04315- 2015-GE-18972)

Table 5. Paired t Test Results of Players' Velocity Pre and Post Test Means

\begin{tabular}{|c|c|c|c|c|}
\hline VELOCITY TESTS & $\begin{array}{c}\text { Test } \\
\text { Sequence }\end{array}$ & $\operatorname{Mean} \pm$ SD & $\mathbf{t}$ & $\mathbf{p}$ \\
\hline \multirow{2}{*}{ Vertical Jump (cm) } & Pre Test & $28.15 \pm 5.48$ & \multirow{2}{*}{-10.37} & \multirow{2}{*}{$.000 *$} \\
\hline & Post Test & $29.85 \pm 5.47$ & & \\
\hline \multirow{2}{*}{ Standing Long Jump (cm) } & Pre Test & $149.50 \pm 12.09$ & \multirow{2}{*}{-6.79} & \multirow{2}{*}{$.000 *$} \\
\hline & Post Test & $153.80 \pm 11.94$ & & \\
\hline
\end{tabular}

$* * * \mathbf{p}<0.05, * * \mathbf{p}<0.01, * \mathbf{p}<0.001$

Differences found to be statistically significant as a result of comparison of players' velocity pre and post test values $(\mathrm{p}<0.05)$.

Table 6. Paired t Test Results of Players' Endurance Pre and Post Test Means

\begin{tabular}{lcccc} 
ENDURANCE TEST & $\begin{array}{c}\text { Test } \\
\text { Sequence }\end{array}$ & Mean \pm SD & t & p \\
\hline Shuttle Run Test & Pre Test & $22.70 \pm 6.20$ & -8.5 & $\mathbf{. 0 0 0 *}$ \\
\cline { 2 - 4 } (number $/ 20$ m) & Post Test & $\mathbf{2 6 . 8 0 \pm 6 . 8 9}$ & & \\
\hline
\end{tabular}

$* * * \mathbf{p}<0.05, * * \mathbf{p}<0.01,{ }^{*} \mathbf{p}<0.001$

There was found significant difference as a result of comparison of players' endurance pre and post test values $(\mathrm{p}<0.05)$.

Table 7. Paired t Test Results of Players' Flexibility Pre and Post Test Means

\begin{tabular}{lllll} 
FLEXIBILITY TEST & $\begin{array}{c}\text { Test } \\
\text { Sequence }\end{array}$ & Mean \pm SD & t & p \\
\hline \multirow{2}{*}{ Sit and Reach Test $(\mathbf{c m})$} & Pre Test & $16.00 \pm 7.01$ & -15.28 & $\mathbf{. 0 0 0 *}$ \\
\cline { 2 - 4 } & Post Test & $\mathbf{1 9 . 4 0 \pm 7 . 1 7}$ & & \\
\hline
\end{tabular}

$* * * \mathbf{p}<0.05, * * \mathbf{p}<0.01,{ }^{*} \mathbf{p}<0.001$ 


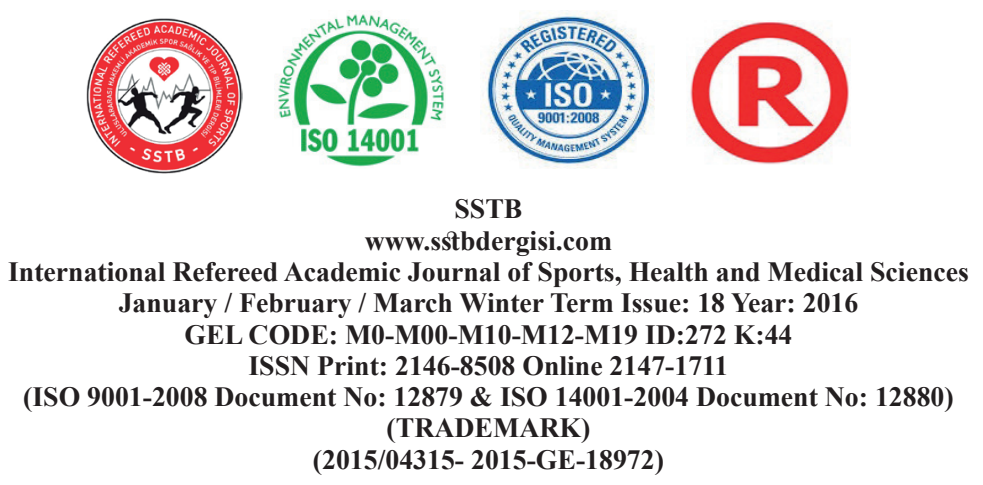

Differences found to be statistically significant as a result of comparison of players' flexility pre and post test values $(\mathrm{p}<0.05)$.

\section{DISCUSSION}

The purpose of this study was to investigate the preparation period trainings' effects on biomotoric features of 10-12 age male tennis players. 20 male tennis players joined to the study whose ages were between 10 and 12 in Isparta. As results of comparison of players' weight, strength (push-up, sit-up, vertical jump, standing long jump), speed (5, 10, $20 \mathrm{~m}$ ), endurance (Shuttle Run) and flexiblity (sit and reach) tests; differences found to be statistically significant in all measurements $(\mathrm{p}<0.05)$.

Aktaş et al. (2011) aimed to investigate the effects of strength trainings on some motoric features of 12-14 age male tennis players. Significant differences found in some strength and endurance (Shuttle Run) pre and post-test values $(\mathrm{p}<0.05)$.

Ölçücü et al. (2011) investigated the effects of movement education with or without ball on physical fitness value of children. As results of weight, speed, vertical jump and strength tests, significant differences found in all tests $(\mathrm{p}<0.05)$.

In a research of Gökgönül (2008) was to investigate the changes of power and some physiological parameters in competition period for seasonal changes at little tennis players (9 - 12 years); differences between pre and post-tests results found to be statistically significant $(\mathrm{p}<0.05)$.

In the study of Kizilet et al. (2011) aimed to investigate the effects of different strength trainings on velocity and jump skills of 12-14 age basketball players. As results of comparison of vertical jump and standing long jump values, differences found to be statistically sifnificant $(\mathrm{p}<0.05)$.

Suna (2013) investigated the effects of aerobic, anaerobic, combine, technique trainings in tennis players on their performances. It was identified that significant differences found in pre and post strength tests $(\mathrm{p}<0.05)$.

In Çalışkan (2014)'s research aimed to investigate the effects of technique and strength trainings on performances of 12-14 age tennis players, it was observed that trainings effected cihldren's strength, speed and coordination features statistically $(\mathrm{p}<0.05)$.

In Faigenbaum et al. (2002)'s research aimed comparison of 1 and 2 days per week of strength training in children, differences found to be statistically significant in strength tests $(\mathrm{p}<0.05)$.

In the research of Filipčič et al. (2015) aimed to identify the differences in physical fitness 


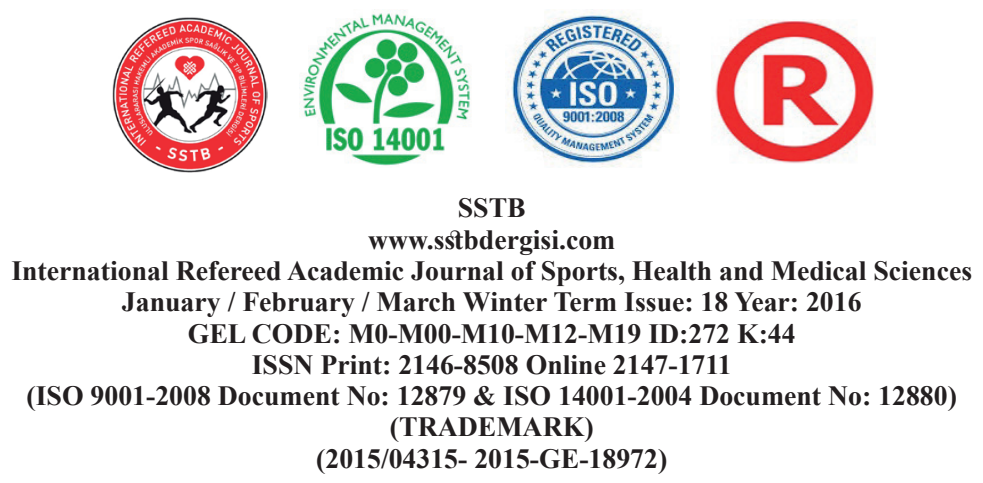

(2015/04315- 2015-GE-18972)

among young tennis players in between 1992 and 2008, significant differences found in strength pre and post-tests $(\mathrm{p}<0.05)$.

In Y1ldırım (2012)'s study aimed to investigate the effects of quick power trainings on 12-14 age basketball beginners' speed, pushup and speed tests were applied to students. As results of these tests, differences found to be statistically siginificant $(\mathrm{p}<0.05)$.

Most of researches, it has been seen that preparation trainings done in earlier ages effected motoric skills of children. It is possible in order to provide the best performance that physical, physiological and psychological backgrounds must been achieved in earlier ages.

\section{RESULTS}

Our study investigated the preparation period trainings' effects on biomotoric features of 10-12 age male tennis players. Significant differences identified from all tests. Players' achievements in the tournaments allowed us to see the efficiency of training and the development of their performances.

It was observed that training drills of technique and coordination for improvement which applied to younger age groups and contented the correct loading densities, developped children's biomotoric features. Considering that biomotoric features are the important factors to effect the performance, we think that the results of our work will contribute a reference value to the tennis coaches and athletes in terms of performance monitoring. Our research offers advices to coaches and sports scientists in terms of training model, content and density to be selected in the studies to be conducted in the future.

\section{REFERENCES}

AKTAŞ, F., AKKUŞ, H., HARBILI, E., HARBILI S., (2011). The Effects Of Strength Trainings On Some Motoric Features Of 12-14 Age Male Tennis Players. Journal Of Physical Education And Sport Sicences, 5 (1)

ÇALIŞKAN, í., (2014). Investigating The Effects Of Technique And Strength Trainings On Performances Of 12-14 Age Tennis Players. Süleyman Demirel University Institute Of Health Sicences Sports Sciences Department, Master Thesis

FAIGENBAUM, A.D., MILLIKEN, L.A., LOUD, R.L., BURAK, B.T., DOHERTY, C.L., WESTCOTT, W.L., (2002). Comparison Of 1 And 2 Days Per Week Of Strength Training In Children, Research Quarterly for Exercise and Sport, 73(4): 416-424

FILIPČIČ, A., FILIPČIČ, T., LESKO ̌̌EK, B., (2015). Differences In Physical Fit- 


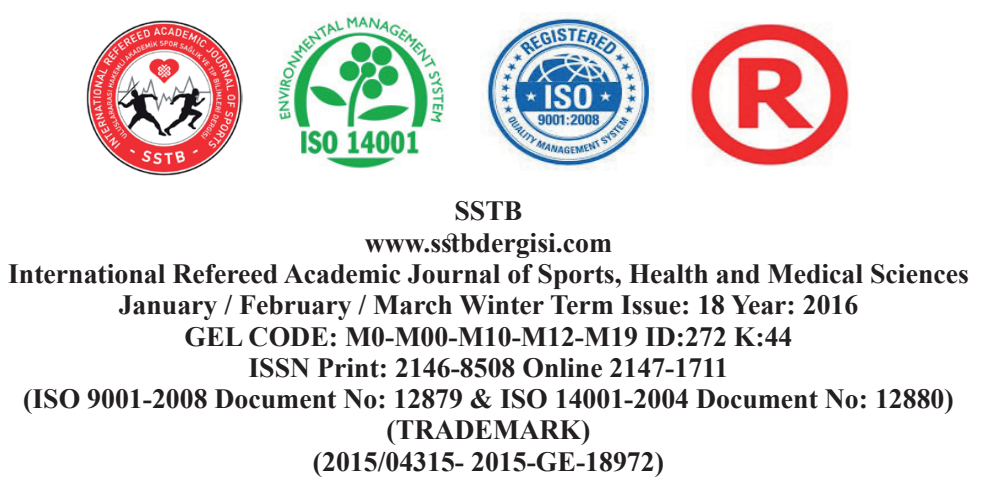

ness Among Young Tennis Players In Between 1992 And 2008. Collegium Antropologicum, 39(1), 131-143

GELEN, E., MENGÜTAY, S., KARAHAN, M., (2009). Analyzing Physical Fitness And Biomechanical Factors Determining Service Performance In Tennis. International Journal of Human Sciences, 6(2): 666-683

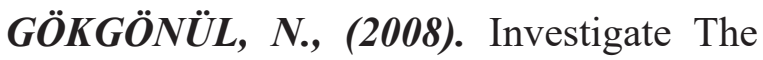
Changes Of Power And Some Physiological Parameters In Competition Period For Seasonal Changes At Little Tennis Players (9-12 Years). Kırıkkale University Institute Of Health Sicences Physical Education and Sports Department, Master Thesis

KIZILET, A., ATILAN, O., ERDEMIR, I., (2010). The Effect Of The Different Strength Training On Quickness And Jumping Abilities Of Basketball Players Between 12 And 14 Age Group. Journal of Physical Education and Sport Sciences, 12(2)

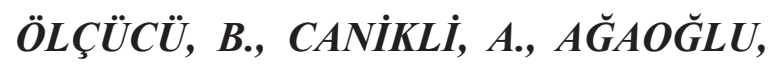
Y.S., ERZURUMLUOĞLU, A., (2010). Evaluating The Factors Of Tennis Skills Development In 10-14 Age Children. Atabesbd; 12(2): 1-11

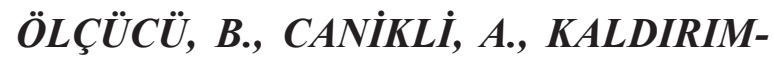
CI, M., BOSTANCI, Ö., (2011). The Effects Of Movement Education With Or Without Ball On Physical Fitness Value Of Children. Journal of Sports and Performance Research, 2(1)

SAHAN, A., (2003). Investigating The Factors Effecting Development Of Tennis Skills At Youths (17-24 Age). Akdeniz University Institute Of Health Sicences Physical Education and Sports Department, Master Thesis

SUNA, G., (2013). The Effects Of Aerobic, Anaerobic, Combine, Technique Trainings In Tennis Players On Their Performances. Süleyman Demirel University Institute Of Health Sicences Sports Sciences Department, Master Thesis

YILDIRIM, G., (2012). Investigating The Effects Of Quick Power Trainings On 12-14 Age Students Of Basketball School. Sakarya University Institute Of Education Sciences Physical Education and Sports Teaching Department, Master Thesis 